\title{
Determination of Threats and Their Relative Severity on Harwood's Francolin (Pternistis harwoodi) at Abahoy Dengera Natural Forest, Awi Administrative Zone, Northwestern Ethiopia
}

\author{
Dessalegn Taye, Edeget Merawi* \\ Email address: \\ edegetmerawi@gmail.com (E. Merawi) \\ ${ }^{*}$ Corresponding author
}

Ethiopian Biodiversity Institute, Bahir Dar Biodiversity Center, Bahir Dar, Ethiopia

To cite this article:

Dessalegn Taye, Edeget Merawi. Determination of Threats and Their Relative Severity on Harwood's Francolin (Pternistis harwoodi) at Abahoy Dengera Natural Forest, Awi Administrative Zone, Northwestern Ethiopia. International Journal of Natural Resource Ecology and Management. Vol. 4, No. 1, 2019, pp. 29-34. doi: 10.11648/j.ijnrem.20190401.15

Received: January 31, 2019; Accepted: March 30, 2019; Published: April 18, 2019

\begin{abstract}
This study was conducted at Abohoye Dengera natural forest to investigate the status of Harwood's Francolin (Pternistis harwoodi) and threats affecting its population. Data were collected using line transect method and questionnaire survey. The main objective of the study was to investigating the status of Pternistis harwoodi and anthropogenic effects at Abohoye Dengera natural forest. A stratified random sampling method was used to assess the Pternistis harwoodi across the four dominant habitat types found in the study area: forest, woodland, scrubland, and farmland. Surveys were conducted during January 2018 and August 2018 which includes both the dry and wet seasons. Data collection was carried out during 6:00 to 10:00 AM, and 4:00 to 6:00 PM, when the activity of birds was more prominent. Line-transect methods were used to collect data on Pternistis harwoodi. The Harwood's Francolin species was estimated using direct (Line transect) and indirect ("calls" of the Harwood's Francolin n) methods. Field data were collected from a total of 8 line transects ranging from $0.5-1 \mathrm{~km}$, each 150-300 m far apart. During the study period a total of 83 Pternistis harwoodi were observed. A total of 60 households are living in the surrounding area. Out of these $30(50 \%)$ of them were interviewed. Major threats reported in the study area included: wildfire, agriculture, hunting, free grazing, predation, and firewood/timber collection. Among all these threats, deforestation was found to be the major threat in the study area, followed by wildfire, free grazing, agriculture, hunting, firewood/timber collection, and predation. Pternistis harwoodi preferred forest habitat followed by farmland, scrubland and wood land. To overcome the above challenges, proper conservation measures have to be taken to solve the problems and prevent the bird from its vulnerable situation.
\end{abstract}

Keywords: Conservation, Harwood Francolin, Threats, Natural Forest

\section{Introduction}

Harwood's Francolin (Pternistis harwoodi) is avian species restricted to the highlands of central Ethiopia around the Abbay River and its tributaries. It is abundant in the high and middle courses of the River. It was entirely restricted to Typha (bulrush) beds growing along small, shallow water courses and Acacia thorn-scrub. The species is now known to occur in scrub, river banks, thickets, rocky areas, dense woodland, and crop land and at the base of cliffs $[22,34,13,28]$.

In Ethiopia, there are 10 species of francolins. The Phasianidae family commonly referred to as "pheasants" includes bird species such as francolins, quails and stone partridge. Of these Harwood's Francolin (Pternistis harwoodi) is the only endemic species. Ethiopia is a country endowed with unique endemic fauna, flora and forest resources. Birds show less endemism than mammals. Pternistis harwoodi is having a range restricted to the central Ethiopian highlands $[2,26,6,12,25,8,15]$. 
Pternistis harwoodi is listed as vulnerable to extinction in the category of threatened bird species of the world. Hunting affects the species. It is heavily hunted for food and is sometimes caught for sale at local market. Anthropogenic activities such as unplanned settlement, developmental activities, intensive agriculture and overgrazing by livestock are challenges to the conservation of the species. Deforestation, firewood, commercial logging, subsistence farming, plantations, and mining are the major causes of the threat. Agricultural intensification can cause decline among the farmland birds [11, 7, 29, 35, 8, 32].

Habitat loss, over-exploitation of wildlife and forest resources and climate change are major causes of biodiversity loss. The situation is most severe in the tropical regions. Human population growth, particularly in developing countries, has intense effects on consumption patterns of land and wild resources, which is considered as an indirect driver of biodiversity loss. Anthropogenic factors can have major impacts on ecosystem functioning and stability, which are often reflected in changes to biodiversity. Increasingly, human population growth coupled with the rise in demand for settlements, agricultural land and wood products is altering important wildlife habitats, bird diversity patterns and overall biodiversity around the world $[9,20,23,18,16]$.

The natural vegetation of Abohoye Dengera has been altered and destroyed by intensive human use including habitat destruction through agriculture, free-grazing, fire, hunting, firewood/ timber collection and predation. These anthropogenic activities are the main threats to Pternistis harwoodi. The study area is also known for its forest coverage and home of Ethiopian endemic Harwood's Francolin but today, the forest is changing into farm land and grazing land. Most of the lowlands have been converted into agricultural and pastoral lands. Therefore, in the light of the stated problems, the main objective of this study was to identify the challenges of Harwood Francolin and to establish appropriate conservation system [Personal observation, 2010].

\section{Materials and Methods}

\subsection{Description of the Study Area}

Abohoye Dengera Natural forest is found in Awi Administrative Zone, Amhara National Regional State, and it lies between $21^{0} 71^{\prime} 99^{\prime \prime}$ to $21^{0} 40^{\prime} 57^{\prime \prime} \mathrm{E}$ latitude, and $129^{0} 12^{\prime} 52^{\prime \prime}$ to $128^{0} 96^{\prime} 00^{\prime \prime} \mathrm{N}$ longitude (Figure 1). The area is located in the north western part of Ethiopia about $507 \mathrm{~km}$ from Addis Ababa, $150 \mathrm{~km}$ from Bair Dar, and $20 \mathrm{~km}$ from Fendeka, the capital of Jawi Woreda. The study area represents Acacia Commiphora Woodland Ecosystem. The area is with low altitude, and the annual mean temperatures ranging between $38.5^{\circ} \mathrm{C}$ to $42^{\circ} \mathrm{C}$ with the mean annual temperature $40.25^{\circ} \mathrm{C}$. The annual precipitation is between $1200 \mathrm{~mm}$ to $1300 \mathrm{~mm}$, with the mean annual rainfall 1250 $\mathrm{mm}$.

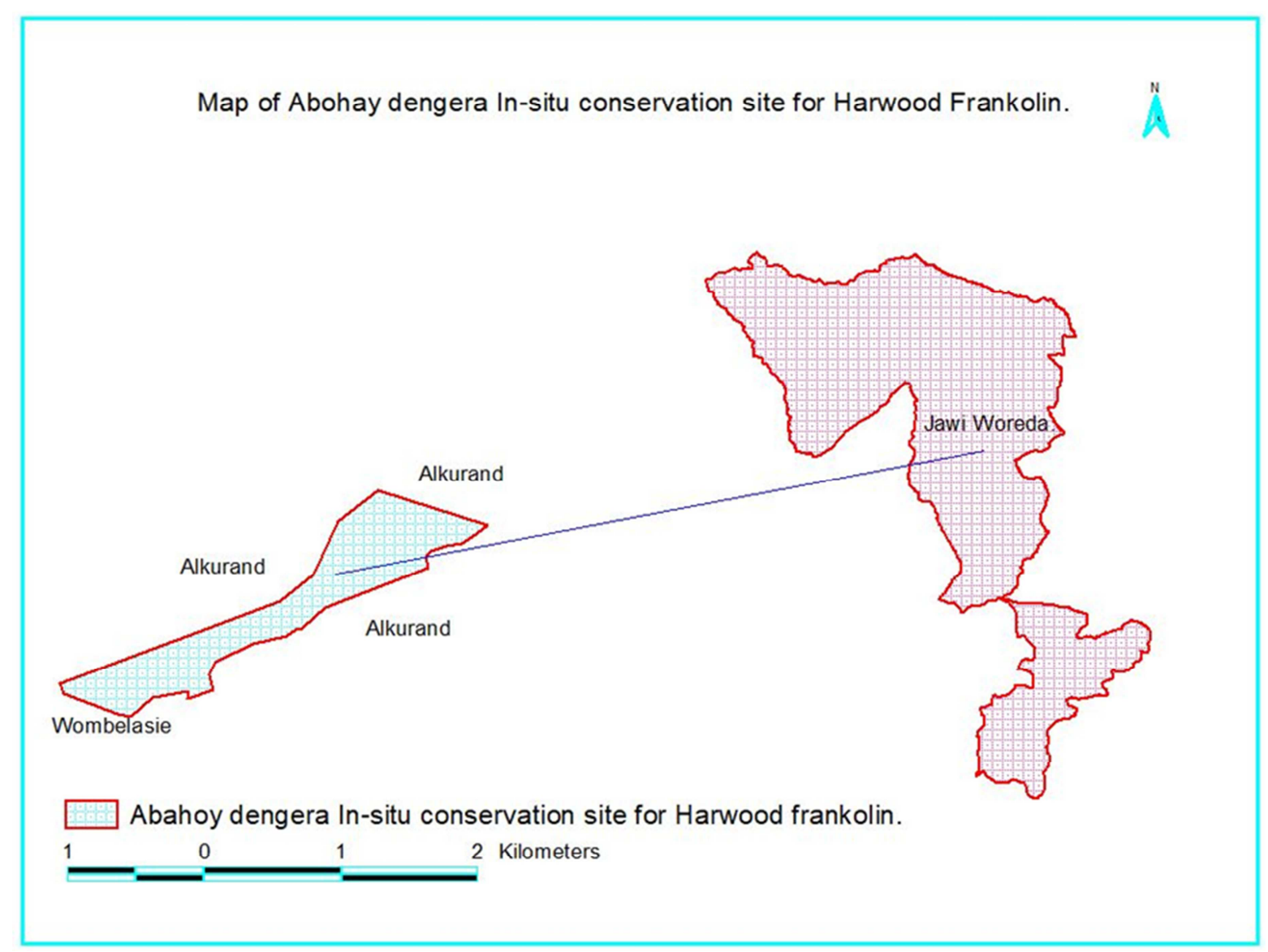

Figure 1. Location map of Abahoy Dengera Natural Forest. 


\subsection{Materials}

Topography map of the study area, Digital camera, 10 x 40 binocular, and Geographic Positioning System (GPS), Sleeping bags, Field tent, Field guidelines, Field shoes, rain coat, note books, Measuring tape, Field guide of birds were used during the survey.

\subsection{Methods}

Preliminary survey was conducted during November 2017 to determine the physical features of the study area and to identify the main threatening factors of Harwood Francolin. The study was conducted in January 2018 and August 2018 during both the dry and wet seasons, respectively. From a total of 60 farmers, who are living in the surroundings area of the present study site $30(50 \%)$ the respondents were interviewed. Focused group discussions with local people and government employees were also conducted. The study was conducted in randomly selected area in the natural forest which covered four habitat types: forest, scrubland, wood land, and farmland based on topography and vegetation structures of the area.
Line transect method was used $[5,31]$ to study Harwood's Francolin survey. Thus, a total of 12 line transects were used in four different habitats. The line transects ranging in length from $0.5 \mathrm{~km}$, each 150 to $300 \mathrm{~m}$. Survey was conducted by walking on the existing footpath and track using the knowledge of standard field guides [27]. Observations were carried out early in the morning (6:00-10:00 AM) and late in the afternoon (4:00-6:00 PM) when bird activities were maximizing [33, 24, 4]. Both direct and indirect methods were applied to estimate the population of Harwood Francolin. The direct method was "line transects method" while indirect population estimation employed the "Calls Method" $[10,30]$. A primary source of data was used to collect information about life history and threats affecting Harwood francolin in Abohoye Dengera natural forest. Primary data sources were field observations, interviews and focus group discussions. A semi-structured interview was prepared to collect the data on the status and threats of Harwood's Francolin in the area. Data were analyzed using descriptive statistics, percentage, frequency; and correlation, and SAS software were used to run the analysis.

\section{Results}

Table 1. Age group frequency and percentage distribution.

\begin{tabular}{|c|c|c|c|c|c|}
\hline \multicolumn{6}{|l|}{ AGE GROUP } \\
\hline AGEGROUP & Frequency & Percent & Cumulative & AGEGROUP & Frequency \\
\hline $15-24$ & 5 & 16.67 & 5 & 16.67 & $15-24$ \\
\hline $25-34$ & 9 & 30.00 & 14 & 46.67 & $25-34$ \\
\hline $35-44$ & 11 & 36.67 & 25 & 83.33 & $35-44$ \\
\hline $45-54$ & 3 & 10.00 & 28 & 93.33 & $45-54$ \\
\hline$>54$ & 2 & 6.67 & 30 & 100.00 & $>54$ \\
\hline
\end{tabular}

Respondents who participated in the interview/ questionnaire were grouped into five age categories i.e. 15-24, $25-34,35-44,45-54$, and $>54$ years. It showed that $16.67 \%$ respondents belonged to age group of $15-24,30 \%$ from $25-34$, $36.67 \%$ from $35-44,10 \%$ from $45-54$ and the remaining $6.67 \%$ respondents were age group of greater than 54 .

Occupation of the respondents showed that $43.33 \%$ of them were engaged with farming and livestock rearing (mixing farming), $40 \%$ were farmers, and $16.67 \%$ were government employees.

Table 2. Occupation frequency and percentage distribution.

\begin{tabular}{lllll}
\hline OCCUPATION & Frequency & Percent & Cumulative \\
\hline Employee & 5 & 16.67 & Frequency \\
Farming & 12 & 40.00 & 5 & Percent \\
Farming and live stock & 13 & 43.33 & 17 & 16.67 \\
\hline
\end{tabular}

Table 3. Educational status frequency and percentage distribution.

\begin{tabular}{|c|c|c|c|c|}
\hline \multicolumn{5}{|l|}{ Educational status } \\
\hline EDUCATIONALSTATUS & Frequency & Percent & Cumulative & Cumulative \\
\hline Degree & 4 & 13.33 & Frequency & Percent \\
\hline Diploma & 1 & 3.33 & 4 & 13.33 \\
\hline Illiterate & 13 & 43.33 & 5 & 16.67 \\
\hline Preparatory & 1 & 3.33 & 18 & 60.00 \\
\hline Primary & 9 & 30.00 & 28 & 93.33 \\
\hline secondary & 2 & 6.67 & 30 & 100.00 \\
\hline
\end{tabular}

Educational level of the respondents indicated that $43.33 \%$ were illiterates, $30 \%$ were primary school completed, $6.67 \%$ were secondary school completed, $3.33 \%$ were preparatory school, $3.33 \%$ were diploma graduates, and $13.33 \%$ were with bachelor degree 
Table 4. Habitat and season association.

\begin{tabular}{llll}
\hline \multicolumn{4}{l}{ Habitat of Harwood francolin by season } \\
\hline Habitat & Seasons & & \\
\hline Frequency & & & \\
Percent & dry & wet & Total \\
Row -Pct & & & \\
Col -Pct & 19 & 13 & 32 \\
& 22.89 & 15.66 & 38.55 \\
forest & 59.38 & 40.63 & \\
& 46.34 & 30.95 & \\
& 5 & 4 & 9 \\
& 6.02 & 4.82 & 10.84 \\
Woodland & 55.56 & 44.44 & \\
& 11.90 & 9.76 & \\
& 10 & 9 & 19 \\
& 12.05 & 10.84 & 22.89 \\
Scrubland & 52.63 & 47.37 & \\
& 24.39 & $211^{\prime} 43$ & \\
& 15 & 8 & 23 \\
Farmland & 18.07 & 9.64 & 27.71 \\
& 65.22 & 34.78 & \\
Total & 35.71 & 19.51 & 83 \\
\hline
\end{tabular}

The number of Harwood's Francolin observed were relatively high $(22.89 \%)$ in the forest habitat during the dry season followed by farmland (18.07\%), scrubland (12.05\%) and the least was woodland $(6.02 \%)$. During the wet season relatively high $(15.66 \%)$ number were recorded in the forest followed by scrubland (10.84\%), farmland $(9.64 \%)$ and the least were listed at woodland habitat $(4.82 \%)$. In general the numbers of Harwood Francolins observed at different habitats showed that forest $(38.55 \%)$, farmland $(27.71 \%)$, scrubland (22.89\%) and woodland (10.84\%).

Table 5. Mean and standard deviation.

\begin{tabular}{lllllll}
\hline Variable & N & Mean & Std. dev & Sum & Minimum & Maximum \\
\hline Habitat & 0 & -- & -- & -- & -- & -- \\
Dry & 4 & 12.2500 & 6.05591 & 49.000 & 5.000 & 19.000 \\
Wet & 4 & 8.5000 & 3.69685 & 34.00 & 4.000 & 13.000 \\
\hline
\end{tabular}

The mean number of Harwood Francolin was highest during the dry season with $12.3+6.05$ individuals and during the wet season with $8.5+3.7$ individuals. Pearson's correlations coefficient there is no association between habitats and seasons.

\section{Discussion}

Majority of the respondents agreed that they have seen Harwood's Francolin in and around Abohoye Dengera natural forest, while some respondents reported replied that as they have seen only sometimes. All of the respondents agreed that the number of Harwood's Francolin declined as they have not frequently seen and heard their calls. According to $[3,19]$ the number of Harwood declined because of different threats including deforestation, fire, free grazing hunting, and agricultural activities. Most participants reported that they didn't see the dead Harwood Francolin; in contrast some respondents suggested that they have seen dead Harwood's Francolin which was killed by traps and sticks thrown by hunters.

Most participants reported that Harwood's Francolin has been eaten by some predators, but, some participants reported that they didn't know the predators of the Harwood's Francolin. Majority of respondents agreed that hawk, wildcat, slender mongoose, serval cat were predators of Harwood's Francolin. The loss of natural habitat has caused Harwood's francolin vulnerable to predators as majority of its shelter has been removed in the area $[13,34]$. Harwood francolin is more vulnerable for predation as compared to other bird species as it built its nest on the ground which is different from other bird species that use the tree for nesting [21].

Majority of the respondents suggested that the Harwood's Francolin had economic value for food meat and egg which is in line with the works of [28, 34]. According to [34] in addition to meat and egg Harwood's Francolin had economic value for medicines such as for asthma and pain. All participants claimed that the Harwood Francolin fed mainly on seeds, crops leaves, fruits, and worms similar to the work of [34].

Most of the respondents suggested that singing in francolins is higher during morning and late in the afternoon which is similar to the work of [1]. Similar to [34] majority of respondents suggested that the breeding season of Harwood's Francolin is from August to December. Some respondents also suggested that the breeding season of francolins was from September to October. In contrast to [17] described that the breeding season of francolins occurs from December to August during which they are mostly seen in pairs and afterwards live in groups. Most of the respondents suggested that the number of eggs laid or clutch-size hatched are 1-7, while other respondents replied that clutch-size reached as 1-5 during which they are mostly live in groups. The results of [4] showed that clutch size in francolin is 3-10.

Majority of respondents suggested that the male Harwood's Francolin was different from the female due to the presence of tarsal spurs bigger red bell and large sized. Some respondents reported that the male has only tarsal spurs than female. Majority of the respondents reported that trap was the common method to hunt Harwood's Francolin. Trap was specifically targeted at francolins, which would walk into the traps and allow a hunter to close up the entrance. Terrestrial birds like Harwood Francolins are easily trapped, and their meat and eggs provide rich sources of protein [14].

Majority of respondents agreed that agriculture was the main threats in Abohoye Dengera natural forest, while some of the respondents were not agreed. Most of the respondents claimed wild fire and hunting are the leading threat to the species in the area. All of the respondents suggested that the Harwood Francolin has declined due to the absence of sufficient trees, shrubs and herbs which is very important for the survival of the species. 


\section{Conclusion}

The highest number Harwood Francolin was recorded in the forest habitat where human disturbance was minimum followed by farmland where sufficient seeds were available; scrubland and the least wood land. The current anthropogenic factors in the natural forest tend to reduce the foraging and nesting opportunities of the Harwood's Francolin. Thus, the main threats to the species understudy are Agriculture, wildfire, free grazing, hunting, firewood collection, and predation. Agriculture is the most important threat that affected the Harwood's Francolin species followed by wild fire. In order to maintain the population of the Harwood's Francolin the habitats of the area should be given high priority conservation measures and this finding could be used to plan conservation of the species with the joint contribution of government and local communities. As the local people living around the natural forest are engaging in farming and livestock activities and largely depend on the natural forest, over utilization of natural resources in the area should be properly managed.

\section{Acknowledgements}

We thank the following individuals namely Mr. Anteneh, Jawi woreda Environmental Regulation and protection team and the local community living around the study area for their contribution during the study period. This research is funded by Ethiopian Biodiversity Institute, Bair Dar Biodiversity Center.

\section{References}

[1] Akhtar S, Kabir MM, Begum S, Hasan MK. 2015. Activity pattern of white-breasted water hen Amaurornis phoenicurus at Jahangirnagar University campus, Savar, Dhaka, Bangladesh. Bangladesh Journal of Zoology 41: 189-198.

[2] Ash, J. and Atkins, J. (2009). Birds of Ethiopia and Eritrea: An Atlas of Distribution. Christopher Helm, London.

[3] Bhattacharya T., Sathyakumar S. \& Rawat G. S. (2009). Distribution and abundance of Galliformes in response to anthropogenic pressures in the buffer zone of Nanda Devi Biosphere Reserve. International Journal of Galliformes Conservation, 1: 78-84.

[4] Bibby, C. J., N. B. Collar, M. J. Crosby, M. F. Heath, C. Imboden, T. H. Jonston, A. J. Long, A. J. Satterfield \& S. J. Thirgood. 1992. Putting Biodiversity on the Map: Priority Areas for Global Conservation. Barrington Press, Cambridge

[5] Bibby, C. J., N. D. Burgess, D. A. Hill \& S. H. Mustoe (Eds) (2000). Bird Census Techniques. 2nd Edition. Academic Press, London, 302pp.

[6] Bird Life International (2014). The Bird Life Checklist of The Birds Of The world: Version 7. Downloaded.

[7] Birdlife International 2017. Species factsheet: Pternistis harwoodi. Www.birdlife.org. Downloaded on 21/02/2017.

[8] Brooke, M. and Birkhead, T. (1991). the Cambridge
Encyclopedia of Ornithology. Cambridge University Press, Cambridge, $362 \mathrm{pp}$.

[9] Brooks, T. M., Mittemeier, R. A., Mittemeier, C. G. and da Fonseca, G. A. B. (2002). Habitat loss and extinction in the hotspots of biodiversity. Conservation Biology, 16: 909-923.

[10] BURFAHM, K. P., ANDERSON, D. R. AND LAAKE. J. L., 1980. Estimation of density from line transects sampling of biological populations. wildl. Monogr., 72; 1-202.

[11] Collar, N. J., M. J. Crosby \& A. J. Satterfield (1994). Birds to Watch 2: The World List of Threatened birds. Bird Life International (Bird Life Conservation Series no. 4), Cambridge, U.K.

[12] Del Hoyo, J., N. J. Collar, D. A. Christie, A. Elliott \& L. D. C. Fish pool (2014). HBW and Bird Life International Illustrated Checklist of the Birds of the World. Lynx editions Bird Life International, 904pp.

[13] Ethiopian wildlife and Natural History Society (EWNHS) (1996). Important Bird Areas of Ethiopia: a first inventory. Ethiopian Wildlife and Natural History Society, Addis Ababa, $300 \mathrm{pp}$.

[14] Fuller, R. A., Carroll, J. P. and McGowan, P. J. K. (2000). Partridges, Quails, Francolins, Stopcocks, Guineafowl and Turkeys. Status Survey and Conservation Action Plan $2000-$ 2004. IUCN and World Pheasant Association, Gland, Switzerland and Cambridge, UK.

[15] ICBP (1992) Putting biodiversity on the map: priority areas for global conservation. Cambridge.

[16] Julliard, Jiguet, J. and Cuvet, D. 2003 common birds facing global changes; what makes species at risk? global change BIol. 10, 148- 154.

[17] Khan, R. A (1997). Status and ecology of Black and Grey Francolin in agricultural land in the Punjab, Pakistan, WPA News, 52: 30-34.

[18] Kideghesho, J. R. (2009). The potentials of traditional African cultural practices in mitigating overexploitation of wildlife species and habitat loss: experience of Tanzania. International Journal of Biodiversity Science \& Management, 5: 83-94.

[19] Kidwai Z. (2013). Effect of anthropogenic factors on the abundance of Galliformes in Sariska Tiger Reserve, Rajasthan, India. Avian Ecology Behavior, 23: 3-13.

[20] Leuschner, C., Moser, G., Hertel, D., Erasmi, S., Leitner, D., Culmsee, H., Schuldt, B. and Chwendenmann, L. (2013). Conversion of tropical moist forest into cacao agro forest: consequences for carbon pools and annual $\mathrm{C}$ sequestration. Agroforestry Systems. 87: 1173-1187.

[21] MARTIN, T. E. 1993. Nest predation and nest sites; new perspectives on old pattern. Bioscience 43; 523-532.

[22] McGowan, P. J. K. 1994. Phasianidae (Pheasants and Partridges). In: Del Hoyo, J.; Elliott, A.; Sargatal, J. (ed.), Handbook of the birds of the world, pp. 434-552. Lynx Editions, Barcelona, Spain.

[23] Michel, S. (2008). Conservation and use of wild Ungulates in central Asia- potentials and challenges. In: R. D. Baldus, G. R. Damn and K. Wollscheid (eds.) Best practices in sustainable hunting- A guide to best practices from around the world. pp. $32-40$. 
[24] Pomeroy, D. (1992). Counting Birds, A guide to Assessing Numbers, Biomass and diversity of afro tropical Birds. African Wildlife Foundation, Nairobi, Kenya, 48 pp.

[25] Rand, A. L. (1967). Ornithology an Introduction. A Signet Book, the New American library, 352 pp.

[26] Redman, C. J., M. Johnes \& S. Marsden (2009). Princeton Field Guides: Birds of the Horn of Africa: Ethiopia, Eritrea, Djibouti, Somalia and Socotra. Christopher Helm, London, 496pp.

[27] Richard Grimmett R, Inskipp C, Inskipp T (2011) Birds of the Indian Subcontinent. Oxford University Press, pp 888.

[28] Robertson, P. A., D. Yilma, D. Sileshi, S. Anteneh, W. Tadesse \& A. Million (1997). Harwood's Francolin francolinus harwoodi: recent observations on its status, distribution, habitat requirements, behavior and threats. Bird Consecration International 7: 275-282; http://doi.org/10.1017/S095927090000157X.

[29] ROBERTS, T. J., 1991. The Birds of Pakistan. Vol. I. Regional studies and non-Passeriformes. Oxford Univ. Press. Karachi, Pakistan, p. 598 Park, Pakistan. Pakistan J. Zool., 44: 1593-1601.

[30] Spiker (1929). A compressive study on the population habitat of the grey.
[31] Thomas, L., S. T Buckland, E. A. Rexstad, J. L. Laake, S. Strindberg, S. L. Hedley, J. R. B. Bishop, T. A. marques \& K. P. Burnham (2010). Distance software: design and analysis of distance sampling surveys for Estimating population size. Journal of Applied Ecology 47: 5-14.

[32] Whited, D., Galatowitsch, S., Tester, J. R., Schik, K., Lehtinen, R. and Husveth, J. (2000). The importance of local and regional factors in predicting effective conservation planning strategies for wetland bird communities in agricultural and urban landscapes. Lands c. Urb. Plan. 49: 49-65.

[33] Williams, J. G. and Arlott, N. (1980). Collins Field Guide to Birds of East Africa. Harper Collins publishers, Hong Kong, $376 \mathrm{pp}$.

[34] Wondafrash, M. (2005). The globally threatened Harwood's Francolin Francolinus harwoodi: range, ecology, threats and conservation measures. Project Terminal Report Submitted to Research program on Sustainable Use of Dry land Biodiversity (RPSUD). Ethiopian Wildlife Natural History society (EWNHS) Addis Ababa, Ethiopia, 36pp.

[35] Zelelew SA. 2013. The birds of Lake Tana Area: a photographic field guide. Addis Ababa: View Graphics Publisher. 